82

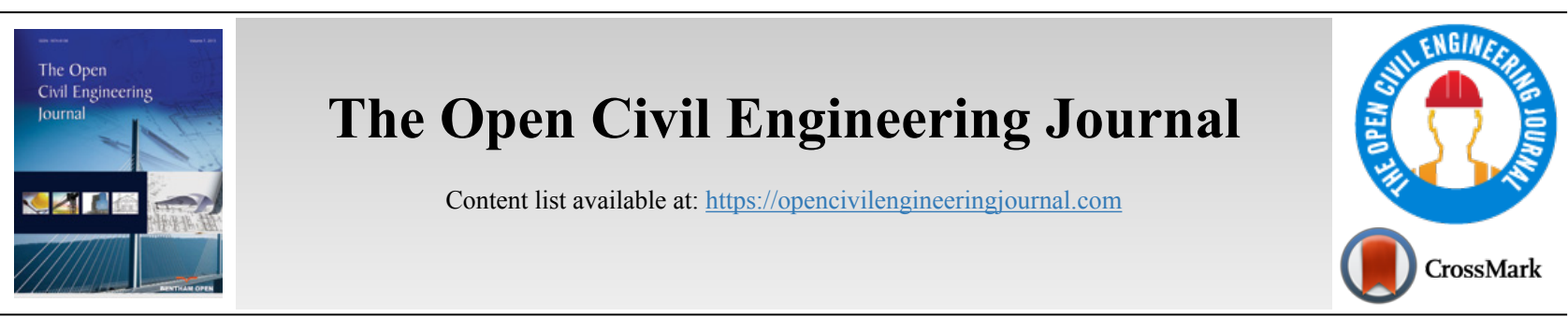

RESEARCH ARTICLE

\title{
Properties of Modified High Permeable Concrete with a Crumb Rubber
}

\author{
Cheng Yee $\mathrm{Ng}^{1, *}$, Anaqi Ratna Narong ${ }^{1}$, Aifaa Balqis Kamarul Zaman ${ }^{1}$, Zahiraniza Mustaffa ${ }^{1}$, Bashar S. Mohammed $^{1}$ \\ and Lee Woen Ean ${ }^{2}$
}

${ }^{\prime}$ Department of Civil and Environmental Engineering, Universiti Teknologi PETRONAS, 32610 Seri Iskandar, Perak, Malaysia

${ }^{2}$ Institute of Sustainable Energy, Universiti Tenaga Nasional, Jalan IKRAM-UNITEN, 43000 Kajang, Selangor, Malaysia

\begin{abstract}
:
Background:

High permeable concrete is designed with high porosity, which allows water to pass through it. By considering this ability, it has been widely used for various applications including high permeable road pavement. However, to fully adopt highly permeable road pavement technology is challenging due to high cost and maintenance, besides, the present engineers and contractors have insufficient expertise and experience with this technology. Henceforth, the high porosity property is highly favorable for road curb applications especially in the tropical region like Malaysia with high rainfall intensity.
\end{abstract}

\section{Objective:}

This paper aimed to determine the properties of the concrete experimentally, and propose the optimum mix design of high permeable concrete for road curb.

\section{Methods:}

The flow value and setting time of the cement paste were investigated. Next, the effects of the modified high permeable concrete with varying amount of crumb rubber on compressive strength, permeability and void ratio were also investigated.

\section{Results and Conclusion:}

Results have revealed that the workability of the cement paste increases when the water-binder ratio and the amount of fly ash increase. Meanwhile, an increasing amount of cement ratio and crumb rubber lowers the flow value and consequently leads to lower void ratio and permeability. Besides, it has been found that the higher the compressive strength, the lower the void ratio and permeability of the concrete. The research findings support that using an optimum amount of cement replacement with crumb rubber as an additive may increase the performance of a high permeable concrete. Herein, the results indicate that the mix design of the concrete studied has the potential to be applied onto the road curb.

Keywords: Crumb rubber, Compressive strength, High permeable concrete, Permeability, Porosity, Void ratio.

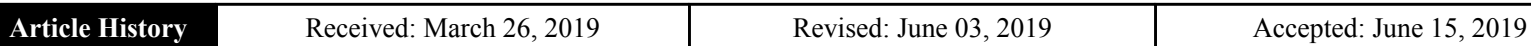

\section{INTRODUCTION}

High permeable concrete is a block of concrete made of a mixture of cement, water, coarse aggregate without or with a small number of fine aggregates. This type of special concrete is different as compared to the conventional concrete since it is mainly designed to have just enough cement paste to coat and connect the coarse aggregate. With that, the high permeable concrete naturally has high porosity and thus the ability to

\footnotetext{
* Address correspondence to this author at the Department of Civil and Environmental Engineering, Universiti Teknologi PETRONAS, 32610, Seri Iskandar, Perak, Malaysia; Tel: +605368731; E-mails: chengyee.ng@utp.edu.my; aifaa_18000268@utp.edu.my
}

allow water to infiltrate through it. Typically, a high permeable concrete, or also, called pervious concrete or porous concrete has a porosity, volume of interconnected voids and permeability approximately $15 \%$ to $25 \%, 15 \%-35 \%$ and $2 \mathrm{~mm} / \mathrm{s}-10$ $\mathrm{mm} / \mathrm{s}$ respectively [1 - 3]. As it is known, the specialty of high permeable concrete is to allow water infiltration at a high rate [3] and due to this property, it has been widely used for various applications including road pavement, parking lots, sidewalks, hydraulic structures and others.

The applications of this concrete are governed by its specialty that it provides a lot of environmental benefits especially in managing and reducing the amount of stormwater 
runoff on the road pavement. The application of high permeable road pavement allows water to penetrate through the concrete, indirectly reducing the risk of road flooding and improving the rate of recharge of groundwater and basins. Besides, it also helps in improving the stormwater quality due to the stormwater runoff infiltration into the ground; the sediment is filtered which prevents contaminants from entering the groundwater which serves as a natural water filter for the environment. Since it is extremely helpful, the high permeable concrete is valued for its application as the best stormwater management practice [4].

Even with all the benefits of high permeable road pavement that have been presented, it is not easy to fully implement it around the world. As stated by Goede [4], due to the low structural performance of the high permeable concrete on the road pavement, the industry is hesitant to apply it due to its inability to sustain heavy loads. In addition, Harvey and Smith [5] mentioned in their report that there is still a lack of expertise and information related to the quality and construction of the permeable pavement. Therefore, this research suggests the application of the concrete onto a road curb instead of road pavements. It should be highlighted that the mixture of the high permeable concrete to be applied in this research was a modified high permeable concrete containing a crumb rubber.

Basically, there are a lot of studies conducted on the conventional concrete with rubber but not much improvement has been made on the high permeable concrete containing rubber until present. Shen et al. [6] carried out a study on polymer-rubber aggregate modified high permeable concrete whereby they replaced mineral aggregates with scrap tire rubber aggregates. Their results showed that the impact resistance, mechanical properties and abrasion improved while the permeability and porosity of the concrete met the required standard of Open-Graded fraction Course. Meanwhile, Gesoglu et al. [7] conducted an experimental investigation on the properties of high permeable concrete containing either tire chips, coarse, a fine crumb rubber or a combination of each. It has been significantly revealed that the properties of the concrete vary depending on the amount and the type of rubber applied. Besides, it has been proven that the use of rubber enhances the ductility and toughness of the concrete.

On the other hand, Bonicelli et al. [8] studied the properties and the effect of high permeable concrete when the fine aggregate was replaced by the crumb rubber. $15 \mathrm{mix}$ designs were used, and the results showed that it is possible to replace the aggregate with a crumb rubber but in correct proportion and with an appropriate granular size. Boon et al. [9] also studied the properties of high permeable concrete but with the replacement of scrap tyre tubes. Their experimental studies have indicated that the use of scrap tyre tubes has increased the flow rate and void content. However, the properties of mechanical strength and the compressive strength of the concrete were reduced significantly as the amount of rubber increased. Similar results were also obtained by Pratibha and Thakelmayum [10] who studied the structural performance of the concrete using crumb rubber and tyre chips.

The most recent study involving rubber was conducted by Liu et al. [11] who researched the effect of rubber dosage and particle size on the mechanical properties, permeability and freeze-thaw resistance towards high permeable concrete. Two sizes, classified as fine and crumb rubber were used with different dosages $(2 \%, 4 \%, 6 \%$ and $8 \%)$. The results have generally revealed that the usage of fine crumb rubber is better than the coarse crumb rubber. The results have also indicated that the increasing amount of crumb rubber has slightly decreased the permeability and strength, yet it improved the freeze-thaw resistance and ductility. The previous study related to high permeable concrete containing rubber had limitations and required more experimental investigations. This research aimed to determine the properties of modified high permeable concrete. While doing so, this research aimed to propose the optimum mix design for high permeable concrete by crumb rubber as an additive. The material used for the modified permeable concrete consists of cement, fly ash, nano-silica, a coarse aggregate, water and a crumb rubber, the properties of which have not been investigated by any other researcher.

\section{MATERIALS AND METHODS}

\subsection{Materials}

In order to produce a modified high permeable concrete, the type of cement used in this research was an Ordinary Portland Cement (OPC) Type 1 in accordance with ASTM C150-04. A partial cement replacement of Class F fly ash (FA) and an additive of Nano-silica (NS) were also used in compliance with the requirement of ASTM C618-03 and ASTM C 1240-03, respectively.

The chemical composition and properties of OPC and FA are presented in Table 1, and the properties of NS are shown in Table 2. A coarse aggregate with a single size of $10 \mathrm{~mm}$ having water absorption of $0.46 \%$ and specific gravity of 2.56 was used.

Table 1. Chemical composition and properties of Ordinary Portland Cement and Fly Ash.

\begin{tabular}{|c|c|c|}
\hline Chemical Composition (\%) & Ordinary Portland Cement & Fly Ash \\
\hline $\mathrm{SiO}_{2}$ & 12.1 & 36.4 \\
\hline $\mathrm{Al}_{2} \mathrm{O}_{3}$ & 1.93 & 14.1 \\
\hline $\mathrm{Fe}_{2} \mathrm{O}_{3}$ & 4.18 & 22.4 \\
\hline $\mathrm{CaO}$ & 75.9 & 17.5 \\
\hline $\mathrm{MgO}$ & 1.03 & 2.55 \\
\hline $\mathrm{Na}_{2} \mathrm{O}$ & - & 0.231 \\
\hline $\mathrm{K}_{2} \mathrm{O}$ & 0.486 & 2.09 \\
\hline $\mathrm{SO}_{3}$ & 3.44 & 1.04 \\
\hline $\mathrm{SiO}_{2}+\mathrm{Al}_{2} \mathrm{O}_{3}+\mathrm{Fe}_{2} \mathrm{O}_{3}$ & 18.21 & 72.9 \\
\hline $\mathrm{Specific} \mathrm{Gravity}_{\text {Loss of ignition }}$ & 3.0883 & 2.7767 \\
\hline & 1.1 & 1.49 \\
\hline
\end{tabular}

Then, the crumb rubber of the waste tyre size ranging between $0.425 \mathrm{~mm}$ to $4.75 \mathrm{~mm}$ which is categorized as fine, was used in the mixture of the concrete.

\subsection{Mix Proportions of High Permeable Concrete and Cementitious Paste}

For the mix proportions, RSM, a design-expert software, was used to determine optimum batches of mix design to be cast from a large number of variables for the mix. The attained results of the mix design were selected based on the ratio of variables inputted in the software. Based on the software, there 
Table 2. Properties of nano-silica.

\begin{tabular}{|c|c|}
\hline Item Appearance & $\begin{array}{c}\text { Features High Dispersive } \\
\text { White Powder }\end{array}$ \\
\hline Heat reduction $(\%)\left(105^{\circ} \mathrm{C}, 2 \mathrm{~h}\right) \leq$ & 3 \\
\hline Loss of ignition $(\%)\left(950^{\circ} \mathrm{C}, 2 \mathrm{~h}\right) \leq$ & 6 \\
\hline $\mathrm{SiO}_{2}$ content $(\mathrm{dry}$ base $)(\%) \geq$ & 92 \\
\hline $\mathrm{SiO}_{2}$ content $(\%)\left(950^{\circ} \mathrm{C}, 2 \mathrm{~h}\right) \geq$ & 99.8 \\
\hline Carbon content $(\%) \geq$ & 0.3 \\
\hline Specific surface area $\left(\mathrm{m}^{2} / \mathrm{g}\right)(\mathrm{BET}$ law $)$ & $100 \pm 25$ \\
\hline $\mathrm{pH}$ value & $6.5-7.5$ \\
\hline Surface density $(\mathrm{g} / \mathrm{ml}) \leq$ & 0.15 \\
\hline Dispensability $(\%)(\mathrm{CCl}) \geq$ & 80 \\
\hline Oil-absorbed value $(\mathrm{ml} / 100 \mathrm{~g}) \geq$ & 250 \\
\hline Average particle $\mathrm{size}(\mathrm{nm})$ & $10-25$ \\
\hline
\end{tabular}

are 15 cement mixtures involved at 5 levels of 3 variables which are FA $(15 \%, 30 \%, 45 \%, 60 \%$ and $75 \%)$, NS (1\%, $2 \%$, $3 \%, 4 \%$ and $5 \%)$ and $\mathrm{CR}(1 \%, 2 \%, 3 \%, 4 \%$ and $5 \%)$ as shown in Table 3.

It has been noted that FA and CR are a partial replacement cement taken by volume. For the mixture proportions of cementitious paste as shown in Table 4, it should be highlighted that it is adapted from Table $\mathbf{3}$ and only one mixture proportion was selected which is CR1-1. The amount of FA, NS and cement remained constant while the amount of CR varied from $1 \%$ to $5 \%$. As suggested by Kevern et al. [12], the water-binder ratio used in this study was 0.3 . Meanwhile, paste/aggregate ratio of 0.382 was used according to the guide provided by the previous researcher [3].

\subsection{Experimental Methods}

The fresh properties of cementitious paste and hardened properties of the high permeable concrete were measured respectively. The details of the experiments are discussed as follows:

\subsubsection{Testing Method of Cementitious Paste}

The flow value test was carried out in accordance with the requirement of ASTM 230-03 [13]. The flow value test was conducted to determine the consistency of fresh concrete, and primarily, for assessing the concrete that is highly workable to be measured using the slump test. Fig. (1a) shows the flow table apparatus that was used for the flow value test. After placing the flow cone at the center of the flow table, the cement paste was poured into the flow cone, followed by tampering on the surface to make sure the cement paste is well compacted. The flow cone was moved upwards and then 15 times of falling motion was reported. The diameter of the cement paste was calculated in the direction where the largest diameter was considered to have been produced and in the direction of right angles to the former. The flow value is the average of these diameters. The time of test was determined in accordance with the requirements of ASTM C 191-04 [14 - 17]. As stated by Chindaprasirt et al. [18], the optimum condition for a cementitious paste of permeable concrete is when the flow value is in the range from $150 \mathrm{~mm}-230 \mathrm{~mm}$.

The final setting was done to see the time when the chemical reaction between the cement and water was finished (The time at which cement completely lost its plasticity and became hard is a final setting time of cement). Fig. (1b) shows the Vicat apparatus. The cement filling the mold was compacted before carrying out the test. The penetration of 1 $\mathrm{mm}$ needle was obtained and recorded for every 15 minutes until the penetration of $5 \mathrm{~mm}$ or less was achieved. It must be taken into account that every penetration test should be at least $5 \mathrm{~mm}$ away from the previous penetration and at least $10 \mathrm{~mm}$ from the inner mold. The final setting time was recorded when the needle did not sink visibly into the paste. The flow value and setting time result could be higher when super-plasticizer was added to the cementitious paste which helped to increase the workability.

Table 3. Mixture proportions of modified high permeable concrete.

\begin{tabular}{|c|c|c|c|c|c|c|}
\hline Mix ID & $\begin{array}{c}\text { Fly Ash } \\
\left(\mathrm{kg} / \mathrm{m}^{3}\right)\end{array}$ & $\begin{array}{l}\text { Nano Silica } \\
\left(\mathrm{kg} / \mathrm{m}^{3}\right)\end{array}$ & $\begin{array}{c}\text { Cement } \\
\left(\mathrm{kg} / \mathrm{m}^{3}\right)\end{array}$ & $\begin{array}{l}\text { Water } \\
\left(\mathrm{kg} / \mathrm{m}^{3}\right)\end{array}$ & $\begin{array}{c}\text { Course Aggregate } \\
\left(\mathrm{kg} / \mathrm{m}^{3}\right)\end{array}$ & $\begin{array}{c}\text { Crumb Rubber } \\
\left(\mathrm{kg} / \mathrm{m}^{3}\right)\end{array}$ \\
\hline CR1-1 & 135.00 & 9.00 & 165.00 & 92.70 & $1,352.52$ & 13.53 \\
\hline CR2-2 & 90.00 & 6.00 & 210.00 & 91.80 & $1,041.36$ & 20.83 \\
\hline CR3-2 & 90.00 & 12.00 & 210.00 & 93.60 & $1,061.78$ & 21.24 \\
\hline CR4-2 & 180.00 & 12.00 & 120.00 & 93.60 & $1,061.78$ & 21.24 \\
\hline CR5-2 & 180.00 & 6.00 & 120.00 & 91.80 & $1,041.36$ & 20.83 \\
\hline CR6-3 & 135.00 & 9.00 & 165.00 & 92.70 & $1,051.57$ & 31.55 \\
\hline CR7-3 & 135.00 & 15.00 & 165.00 & 94.50 & $1,071.99$ & 32.16 \\
\hline CR8-3 & 45.00 & 9.00 & 255.00 & 92.70 & $1,051.57$ & 31.55 \\
\hline CR9-3 & 135.00 & 3.00 & 165.00 & 90.90 & $1,031.15$ & 30.93 \\
\hline CR10-3 & 225.00 & 9.00 & 75.00 & 92.70 & $1,051.57$ & 31.55 \\
\hline CR11-4 & 90.00 & 12.00 & 210.00 & 93.60 & $1,061.78$ & 42.47 \\
\hline CR12-4 & 90.00 & 6.00 & 210.00 & 91.80 & $1,041.36$ & 41.65 \\
\hline CR13-4 & 180.00 & 12.00 & 120.00 & 93.60 & $1,061.78$ & 42.47 \\
\hline CR14-4 & 180.00 & 6.00 & 120.00 & 91.80 & $1,041.36$ & 41.65 \\
\hline CR15-5 & 135.00 & 9.00 & 165.00 & 92.70 & $1,051.57$ & 52.58 \\
\hline
\end{tabular}


Table 4. Mixture proportions of cementitious paste.

\begin{tabular}{|c|c|c|c|c|c|}
\hline Mix ID & $\begin{array}{c}\text { FA } \\
(\%)\end{array}$ & NS (\%) & $\begin{array}{c}\text { Cement } \\
(\%)\end{array}$ & Water-Binder Ratio & CR (\%) \\
\hline CR1-1a & 75 & 1 & 25 & 0.30 & 1 \\
\hline CR1-1b & 75 & 1 & 25 & 0.30 & 2 \\
\hline CR1-1c & 75 & 1 & 25 & 0.30 & 3 \\
\hline CR1-1d & 75 & 1 & 25 & 0.30 & 4 \\
\hline CR1-1e & 75 & 1 & 25 & 0.30 & 5 \\
\hline
\end{tabular}

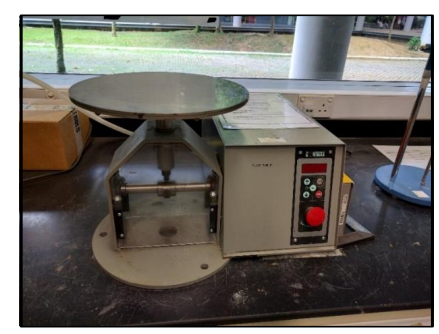

(a) Flow table apparatus

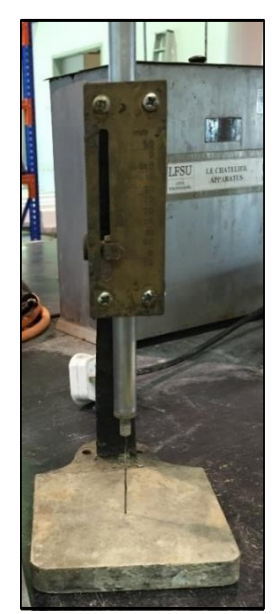

(b) Vicat apparatus
Fig. (1). Testing apparatus for cementitious paste.

\subsubsection{Testing Method of High Permeable Concrete}

Compressive strength test was carried out in accordance with the requirement of ASTM C39-03, the standard test method for compressive strength of concrete specimens. A compression machine as shown in Fig. (2a) has been used in this test. A constant rate of $3 \mathrm{kN} / \mathrm{s}$ loading was applied to concrete cube samples when the test was being conducted. For testing of high permeable concrete, a sample of $100 \times 100 \times$ $100 \mathrm{~mm}$ cube was prepared, cast and tested at 28 days. All the specimens were compacted by a tempered rod. The compressive strength of the specimen was calculated by using Eq. (1) below:

$$
f_{i}=P_{i} / A
$$

where $f_{i}$ is the ultimate compressive strength $(M P a), P_{i}$ is the maximum axial load applied $(N)$ and $A$ is the crosssectional area of the cylinder $\left(\mathrm{mm}^{2}\right)$.

The void ratio of high permeable concretes was determined with reference to the method described in the ASTM C1754- 2 [15], which is the standard test method for determining density and void content of the permeable hardened concrete. The concrete cubes were kept for 24 hours before the reading $W_{2}$ was recorded. The void ratio was calculated by using the weight difference between the air-dry sample and the saturated sample underwater, as shown in Eq. (2).

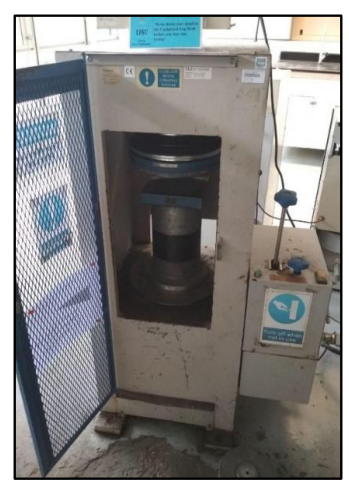

(a) Compression machine

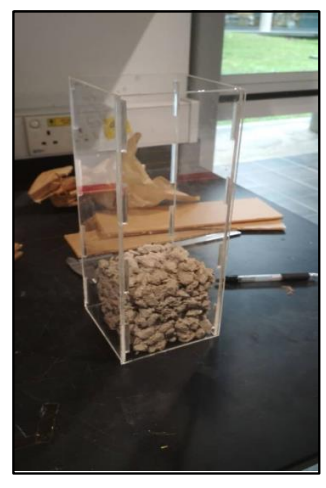

(b) Permeability device
Fig. (2). Testing apparatus for cementitious paste.

$$
V=\left[\left(\frac{W_{2}-W_{1}}{\rho_{w} \text { Vol }}\right)\right] \times 100 \%
$$

where $V$ is the total percent (\%), $W_{1}$ is the mass of the saturated sample $(\mathrm{kg}), W_{2}$ is the mass of the oven dry sample $(\mathrm{kg}), \mathrm{Vol}$ is the volume of the sample $\left(\mathrm{cm}^{3}\right)$ and $\tilde{\mathrm{n}}_{\mathrm{w}}$ is the density of water, $\left(\mathrm{kg} / \mathrm{m}^{3}\right)$.

Permeability tests of the permeable concrete samples were carried out with reference to the apparatus designed as shown in Fig. (2b) [16]. This test was carried out to see the performance of permeable concrete filtrate with the average Malaysian's precipitation. A sample of $100 \times 100 \times 100 \mathrm{~mm}$ was prepared and used for this test. A device of $100 \times 100 \times$ $300 \mathrm{~mm}$ with an opening at both ends was designed.

The surface of the sample was air-proofed with the modelling clay before measurement. Later, the device was placed on the sample. The modelling clay was used to air-proof the gap between the device and the sample. After the clay was set to the desired state, water was poured into the device until the water line reached $200 \mathrm{~mm}$. A timer was started when the water line dropped to $160 \mathrm{~mm}$, and the timer was stopped when the water line reached $140 \mathrm{~mm}$. The coefficient of permeability was calculated using Eq. (3) below:

$$
V=H / t
$$

where $V$ is the water penetration coefficient $(\mathrm{mm} / \mathrm{s}), H$ is the height of the water line from $160 \mathrm{~mm}$ to $140 \mathrm{~mm}(20 \mathrm{~mm})$ and $t$ is the time $(s)$ when the water line fell from $160 \mathrm{~mm}$ to $140 \mathrm{~m}$.

\section{RESULTS AND DISCUSSION}

\subsection{Cementitious Paste Properties}

The test results for cementitious paste such as flow value and setting time are presented in Table $\mathbf{5}$. 
Table 5. Mix proportions, flow value and setting time for the cementitious paste.

\begin{tabular}{|l|c|c|c|c|c|c|c|}
\hline Mix ID & $\begin{array}{c}\text { FA } \\
\text { (\%) }\end{array}$ & $\begin{array}{c}\text { NS } \\
(\%)\end{array}$ & $\begin{array}{c}\text { Cement } \\
(\mathbf{\%})\end{array}$ & $\begin{array}{c}\text { Water-Binder } \\
\text { Ratio }\end{array}$ & $\begin{array}{c}\text { CR } \\
(\%)\end{array}$ & $\begin{array}{c}\text { Flow } \\
\text { Value } \\
(\mathbf{m m})\end{array}$ & $\begin{array}{c}\text { Setting } \\
\text { Time } \\
(\mathbf{m i n})\end{array}$ \\
\hline CR1-1a & 75 & 1 & 25 & 0.30 & 1 & 203 & 250 \\
\hline CR1-1b & 75 & 1 & 25 & 0.30 & 2 & 195.5 & 265 \\
\hline CR1-1c & 75 & 1 & 25 & 0.30 & 3 & 189 & 290 \\
\hline CR1-1d & 75 & 1 & 25 & 0.30 & 4 & 183 & 360 \\
\hline CR1-1e & 75 & 1 & 25 & 0.30 & 5 & 178 & 400 \\
\hline
\end{tabular}

\subsubsection{Flow Value}

$1 \%, 2 \%, 3 \%, 4 \%$ and $5 \%$ crumb rubber were selected to be tested with the $\mathrm{w} / \mathrm{b}$ of 0.3 . A water-binder ratio of 0.3 was used because it is within the range as suggested by researchers which is $180 \mathrm{~mm}-250 \mathrm{~mm}$ [17]. The ratio was also chosen to be a lower $\mathrm{w} / \mathrm{b}$ ratio that resulted in a higher porosity of concrete which is favourable for high permeable concrete. The test revealed that when a higher dosage of crumb rubber was used, it reduced the workability of the cement paste. This was caused by the dispersion problem and conglomeration of mixed materials. From Fig. (3), it can be noticed that the increase in the crumb rubber percentage resulted in a lower flow value. To cope up with this issue, a superplasticizer was added in a suitable amount in order to maintain the workability of the cement paste with an allowable flow value of minimum $150 \mathrm{~mm}$ [17]. With the addition of the superplasticizer into the mortar mix, the flow value increases.

\subsubsection{Final Setting Time}

By using the same mix proportions of cement paste as shown in Table 5, the final setting time for the cement paste increased as the percentage of crumb rubber replacement increased as shown in Fig. (4). According to the flow value results, $0.3 \mathrm{w} / \mathrm{b}$ ratio was chosen as the water-binder ratio for this test because it was within the range as suggested by researchers [17]. The final setting time of cement paste without any crumb rubber addition for water-binder ratio 0.30 was 230 minutes. While the final setting time for cement paste with the addition of $1 \%$ to $5 \%$ crumb rubber ranged between 250 minutes to 400 minutes. This result was in good agreement with the research conducted by Webster et al. [18]. From the above results, the increment in the content of crumb rubber in the mortar was found to be reducing the flow value, but vice versa for the final setting time. This result is in good agreement with the result shared by Meherier et al. [19]. However, with the addition of a superplasticizer, the final setting time increased.

\subsection{High Permeable Concrete Properties}

The test result for high permeable concrete such as void ratio, compressive strength and permeability is presented in Table 6.

\subsubsection{Void Ratio}

Fig. (5) shows the relationship between the void ratio of the hardened concrete and the various mix design batches. Based on the results, mix design 7 with the highest Nano-silica ratio showed the highest void ratio, while the lowest void ratio was obtained by mix design 15 with the highest ratio of crumb rubber. The void ratio of the mix design batches ranged from $13.84 \%$ to $17.44 \%$. It is recommended that the targeted void content of a high permeable concrete is between $15 \%$ to $25 \%$ as measured by ASTM C $1688[1,13]$.

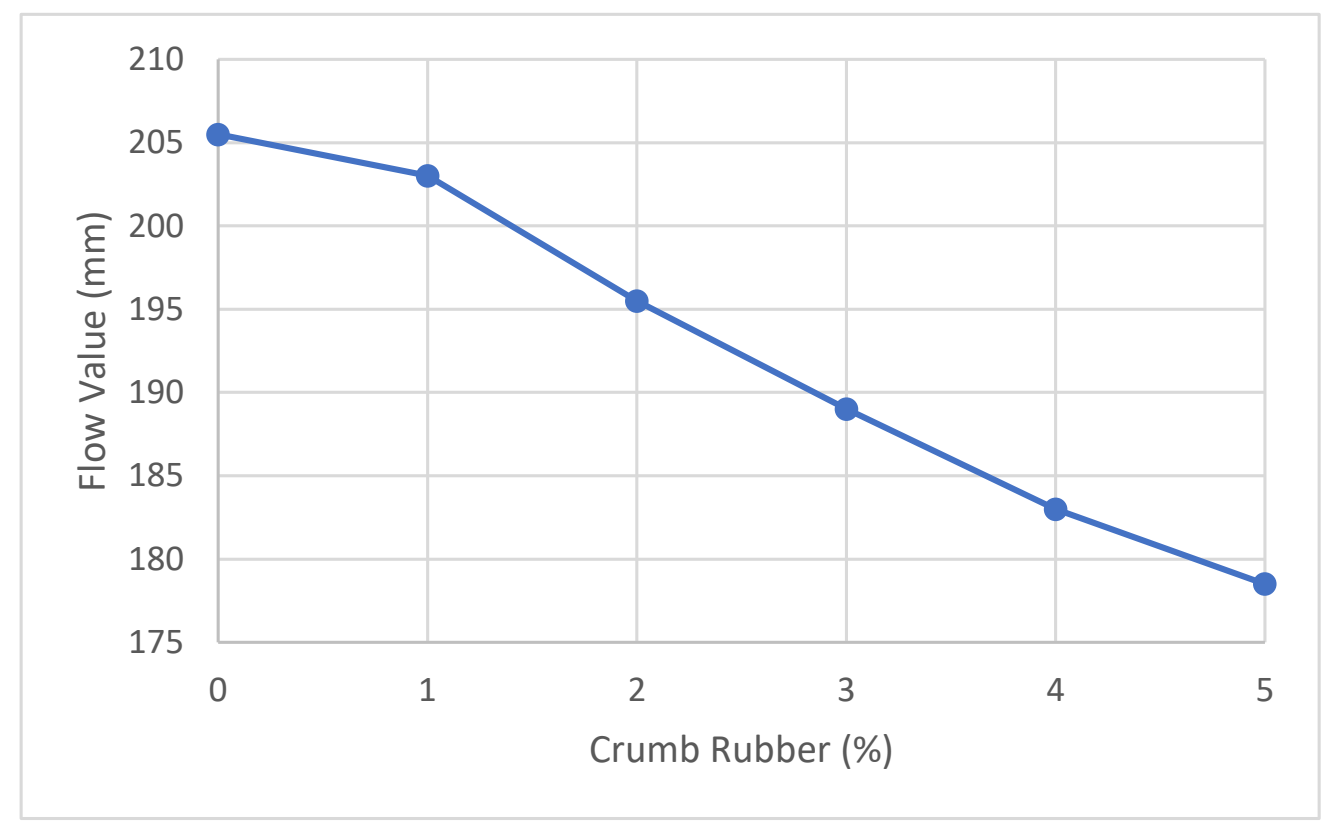

Fig. (3). Graph of flow value $v s$ crumb rubber. 


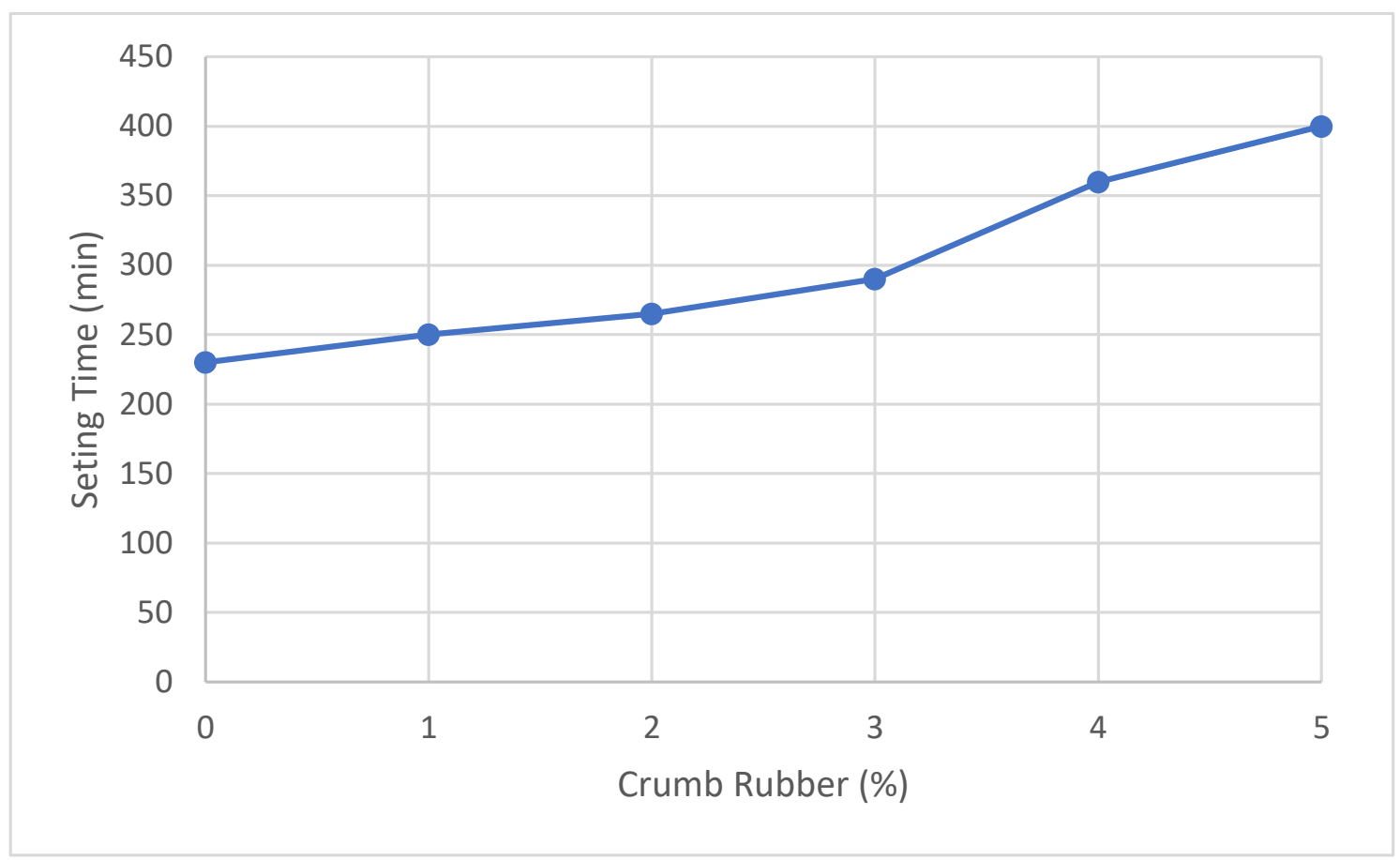

Fig. (4). Graph of setting time vs crumb rubber.

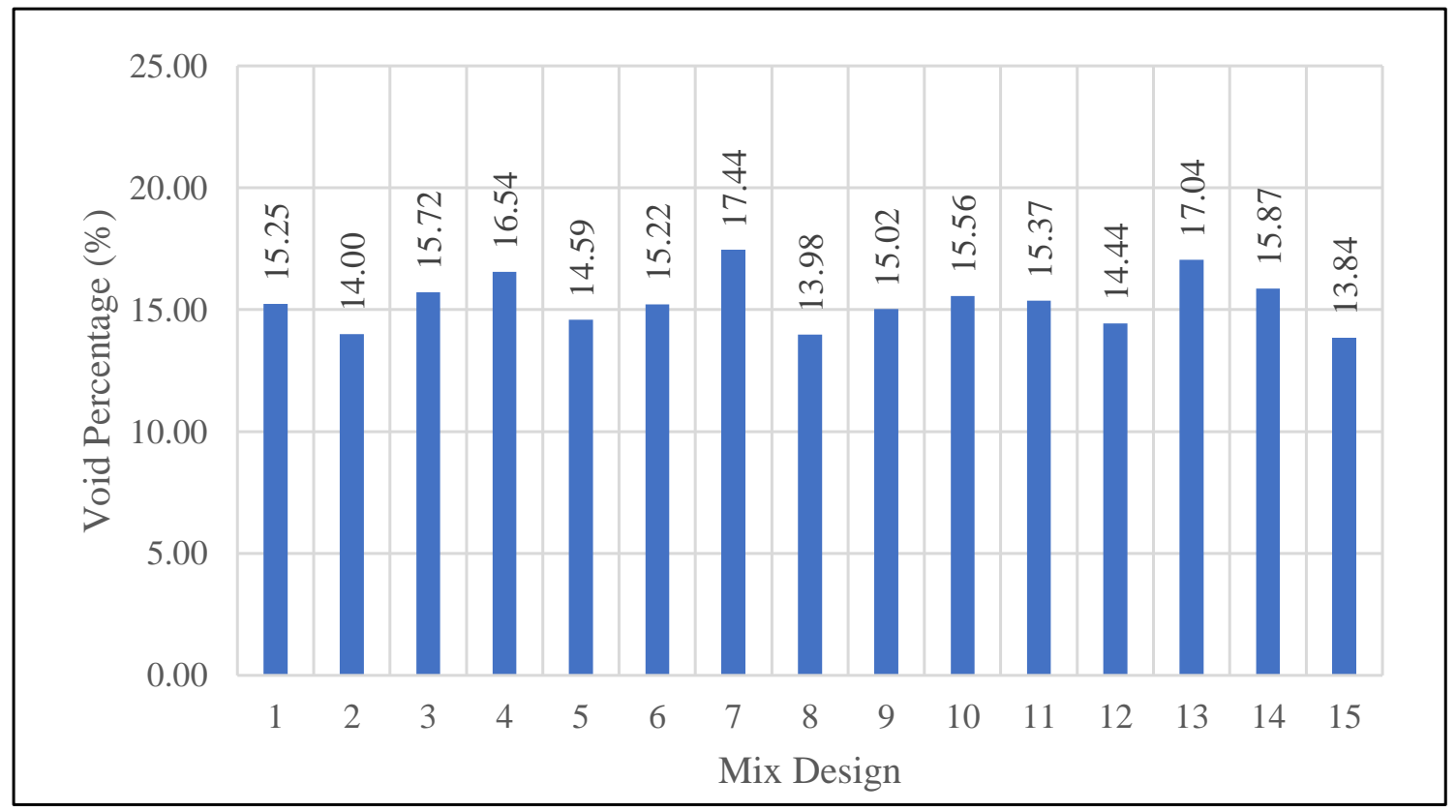

Fig. (5). Graph of void ratio vs mix design.

Results clearly show that as the crumb rubber ratio increases, the void ratio in the concrete decreases. This happens because of variation in the amount of the crumb rubber in the concrete component. The higher amount of crumb rubber fills the gap of the void between the coarse aggregate as in high permeable concrete, which is the key to maximize porosity in the concrete to infiltrate more water. Having a crumb rubber is like substituting fine aggregates which supposedly is not included in a high permeable concrete, thus effectively filling the voids between the aggregates. However, a small amount of fine aggregates as sand may be added to provide additional compressive strength, better durability and higher resistance to freeze and thaw cycles [20]. 
Table 6. Void ratio, compressive strength and void ratio of high permeable concrete.

\begin{tabular}{|c|c|c|c|c|c|c|}
\hline Mix ID & $\begin{array}{c}\text { FA } \\
\mathbf{( \% )}\end{array}$ & $\begin{array}{c}\text { NS } \\
\mathbf{( \% )}\end{array}$ & $\begin{array}{c}\text { CR } \\
\mathbf{( \% )}\end{array}$ & Void Ratio (\%) & $\begin{array}{c}\text { Compressive Strength } \\
\text { (MPa) }\end{array}$ & Permeability (mm/s) \\
\hline CR1-1 & 45 & 3 & 1 & 15.25 & 2.40 & 4.62 \\
\hline CR2-2 & 30 & 2 & 2 & 14.00 & 8.81 & 3.44 \\
\hline CR3-2 & 30 & 4 & 2 & 15.72 & 2.05 & 7.86 \\
\hline CR4-2 & 60 & 4 & 2 & 16.54 & 2.08 & 3.49 \\
\hline CR5-2 & 60 & 2 & 2 & 14.59 & 3.04 & 3.89 \\
\hline CR6-3 & 45 & 3 & 3 & 15.22 & 2.13 & 6.80 \\
\hline CR7-3 & 45 & 5 & 3 & 17.44 & 8.33 & 3.12 \\
\hline CR8-3 & 15 & 3 & 3 & 13.98 & 2.93 & 4.47 \\
\hline CR9-3 & 45 & 1 & 3 & 15.02 & 1.71 & 9.92 \\
\hline CR10-3 & 75 & 3 & 3 & 15.56 & 2.31 & 5.87 \\
\hline CR11-4 & 30 & 4 & 4 & 15.37 & 5.03 & 3.51 \\
\hline CR12-4 & 30 & 2 & 4 & 14.44 & 2.45 & 4.22 \\
\hline CR13-4 & 60 & 4 & 4 & 17.04 & 4.44 & 3.55 \\
\hline CR14-4 & 60 & 2 & 4 & 15.87 & 3.75 & 3.68 \\
\hline CR15-4 & 45 & 3 & 5 & 13.84 & & \\
\hline
\end{tabular}

It was also noticed that the mix design 8 with the highest cement ratio is ranked as the second lowest void ratio value. This makes it possible that cement replacement percentage is directly proportional to the void ratio which is due to the amount of C-S-H gel produced. A higher amount of cement produces more calcium hydroxide $\mathrm{Ca}(\mathrm{OH})_{2}$ which eventually is converted into calcium silicate hydrate $(\mathrm{C}-\mathrm{S}-\mathrm{H})$ via the pozzolanic reaction. Calcium silicate hydrate fills the pores in the cement, and hence lowers the void ratio in the concrete.

\subsubsection{Compressive Strength}

The compressive strength for the permeable concrete with paste/aggregate ratio 0.382 as suggested by C'osic et al. [21] is shown in Fig. (6). From the result, the high permeable concrete mixtures have been found to develop compressive strengths in the range of $1.71 \mathrm{MPa}$ to $8.81 \mathrm{MPa}$ which is suitable for a wide range of applications. It was observed that the higher cement ratio inside the mix design increased the compressive strength. This is because as the amount of cement paste being used in the mixture is increased, the cement paste gets coated around the aggregates more effectively and thus resulting in a higher compressive strength.

It has been noticed that as the cement replacement (fly ash) percentage increases, the compressive strength of the permeable concrete decreases. This is because with the reduction of cement content, the amount of $\mathrm{Ca}(\mathrm{OH})_{2}$ produced is lower, and the amount of C-S-H gel produced reduces as well. However, currently, there is no ASTM test standard for determining the compressive strength of the permeable concrete. Testing variability measured with various draft test

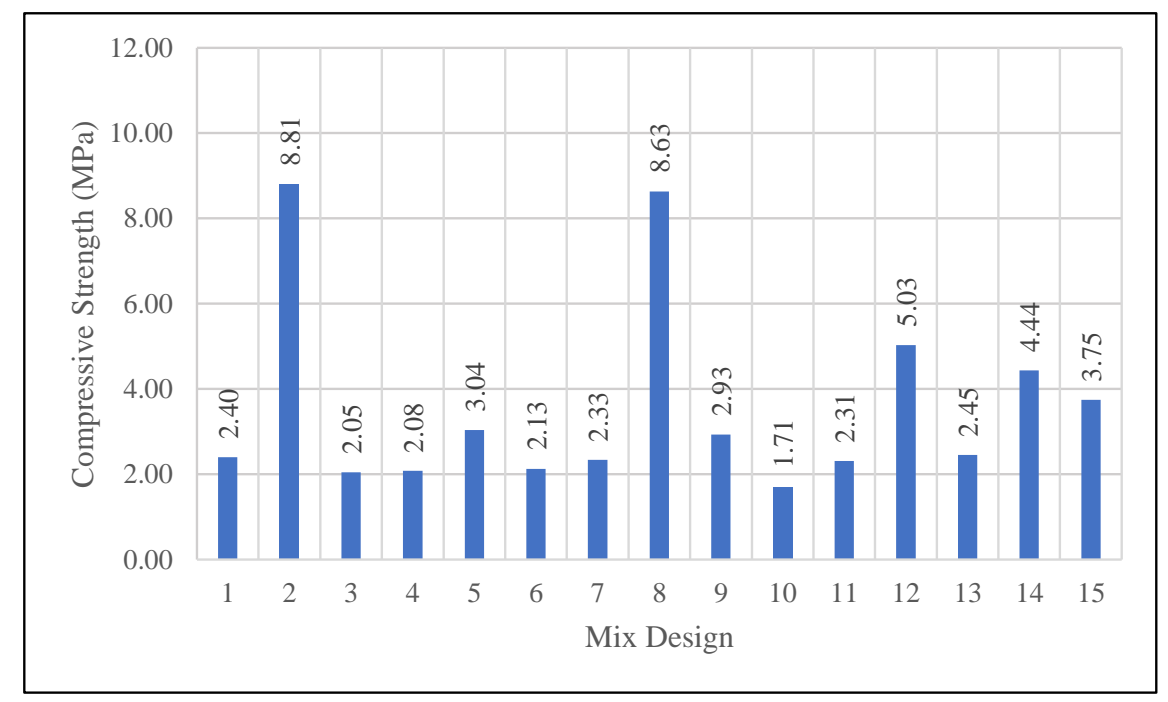

Fig. (6). Graph of compressive strength $v s$ mix design. 
methods has been found to be high, and therefore, compressive strength is not recommended as an acceptance criterion. Rather, it is recommended that a target void content (between $15 \%$ to $25 \%$ ) as measured by ASTM C 1688: Standard Test Method for Density and Void Content of Freshly Mixed Pervious Concrete [15], be specified for quality assurance and acceptance.

\subsubsection{Permeability}

The relationship of the permeability of the high permeable concrete and the mix design is shown in Fig. (7). From the results obtained, it becomes clear that all the mix designs can infiltrate the Malaysian average precipitation which is 0.754 $\mathrm{m} / \mathrm{s}$ [22]. This is accepted for permeability test, as there is still no standard requirement, however, ASTM for a high permeable concrete is still considered a newly developed type of concrete [1].

As shown in the results above, it was found that the permeability of the high permeable concrete ranged from 3.44 $\mathrm{mm} / \mathrm{s}$ to $9.92 \mathrm{~mm} / \mathrm{s}$. The permeability of the permeable concrete is directly proportional to the void ratio. The permeability of the permeable concrete was also observed to be related to the cement ratio as a higher amount of cement present in the mixture reduced more cement coating around the aggregate and eventually reduced the permeability of the permeable concrete.

The increased content of fly ash in the mixture has shown to increase the void ratio which can be seen in the mix design 10 which has the highest ratio of cement replacement. This is similar to the void ratio test. The difference in the void ratio is because of the low amount of calcium silicate hydrate produced with the increase of cement replacement in the mixture.

The flow rate through permeable concrete depends on the materials and placing operations. Typical flow rates for water through permeable concrete are $2.0 \mathrm{~mm} / \mathrm{s}$ to $5.4 \mathrm{~mm} / \mathrm{s}$, with higher rates of up to $12 \mathrm{~mm} / \mathrm{s}$ [1]. From the results, it can be noticed that the permeability of high permeable concrete is inversely proportional to the compressive strength.

\subsection{Optimum Mix Design of High Permeable Concrete}

Based on the overall performances of the test results, the high permeable concrete selection design matrix is shown in Table 7. The overall high permeable concrete performance was selected based on different requirements. For void ratio property, the selections were based on the standard requirement of high permeable concrete which ranged from $15 \%$ to $25 \%$. For permeability rate property, the selections were based on the comparison of Malaysia's average precipitation in millimetre per second rate which is $2.0 \mathrm{~mm} / \mathrm{s}$ to $5.4 \mathrm{~mm} / \mathrm{s}$, with higher rates of up to $12 \mathrm{~mm} / \mathrm{s}$.

For compressive strength, since there is no standard requirement for high permeable concrete, the compressive strength of the concrete ranged from the highest to the lowest value. The results above show that out of the 15 mix designs, five of them do not meet the standard requirements which are not applicable for a high permeable concrete. Based on the ranking of all mix designs, the optimum mix design of high permeable concrete that can be used is the mix design CR14-4. This is because it met all the standard requirements of an easily applicable high permeable concrete based on its performance of void ratio, permeability and compressive strength.

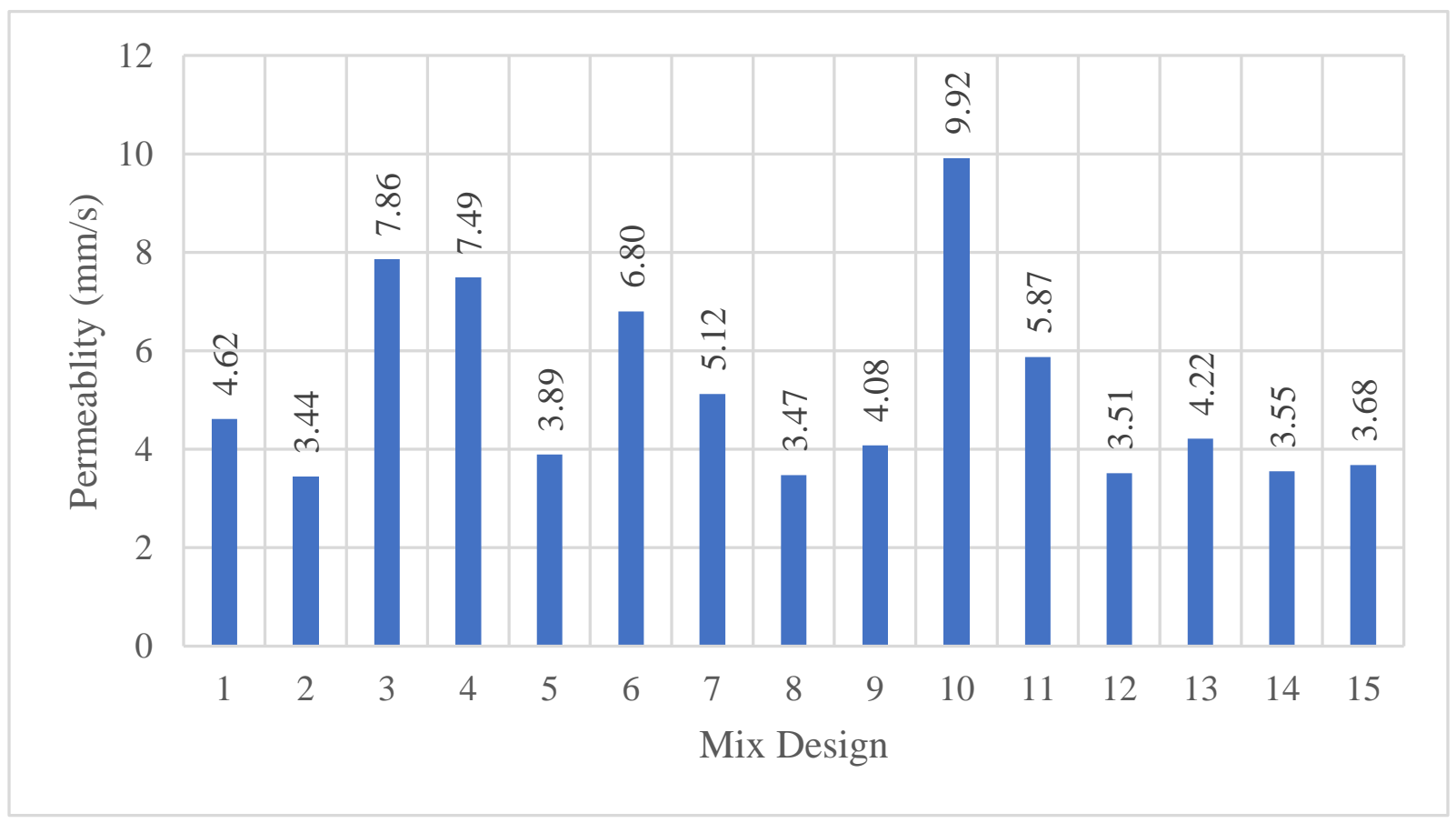

Fig. (7). Graph of permeability $v s$ mix design. 
Table 7. Ranking of modified high permeable concrete.

\begin{tabular}{|c|c|c|c|c|}
\hline Mix ID & $\begin{array}{c}\text { Void } \\
\text { Ratio }\end{array}$ & $\begin{array}{c}\text { Permeability } \\
\text { Rate }\end{array}$ & $\begin{array}{c}\text { Compressive } \\
\text { Strength }\end{array}$ & Ranking \\
\hline CR1-1 & $/$ & $/$ & $9^{\text {th }}$ & $4^{\text {th }}$ \\
\hline CR2-2 & $\mathrm{X}$ & $/$ & $1^{\text {st }}$ & Disqualified \\
\hline CR3-2 & $/$ & $/$ & $14^{\text {th }}$ & $\mathbf{9}^{\text {th }}$ \\
\hline CR4-2 & $/$ & $/$ & $13^{\text {th }}$ & $\mathbf{8}^{\text {th }}$ \\
\hline CR5-2 & $\mathrm{X}$ & $/$ & $6^{\text {th }}$ & Disqualified \\
\hline CR6-3 & $/$ & $/$ & $12^{\text {th }}$ & $7^{\text {th }}$ \\
\hline CR7-3 & $/$ & $/$ & $10^{\text {th }}$ & $\mathbf{5}^{\text {th }}$ \\
\hline CR8-3 & $\mathrm{X}$ & $/$ & $2^{\text {nd }}$ & Disqualified \\
\hline CR9-3 & $/$ & $/$ & $7^{\text {th }}$ & $\mathbf{2}^{\text {nd }}$ \\
\hline CR10-3 & $/$ & $/$ & $15^{\text {th }}$ & $\mathbf{1 0}^{\text {th }}$ \\
\hline CR11-4 & $/$ & $/$ & $11^{\text {th }}$ & $\mathbf{6}^{\text {th }}$ \\
\hline CR12-4 & $\mathrm{X}$ & $/$ & $3^{\text {td }}$ & Disqualified \\
\hline CR13-4 & $/$ & $/$ & $8^{\text {th }}$ & $3^{\text {rd }}$ \\
\hline CR14-4 & $/$ & $/$ & $4^{\text {th }}$ & $\mathbf{1}^{\text {st }}$ \\
\hline CR15-4 & $\mathrm{X}$ & $/$ & $5^{\text {th }}$ & Disqualified \\
\hline
\end{tabular}

\section{CONCLUSION}

The properties of modified high permeable concrete containing crumb rubber were examined thoroughly, and the optimum mix design was also successfully determined throughout this research. Herein, the tests for flow value, setting time, permeability, compressive strength and void ratio of the permeable concrete were also carried out. The following conclusions were drawn based on the test and analysis of results:

[1] The effects of cement replacement, fly ash, Nano silica and crumb rubber as additives with the watercementitious material ratio on the fresh properties of cement paste are outlined as below:

- The workability of cement paste increased with a higher water-binder ratio used in the cement paste. However, the workability could be adjusted and increased by using a proper amount of superplasticizer. Fly ash replacement can increase the workability and the properties of the cement paste. However, excessive use of replacement material should be avoided, as this will reduce the performance of the hardened properties of the permeable concrete.

- Increment of crumb rubber content in the mortar was found to be reducing the flow value, but vice versa for final setting time.

[2] The effects of cement replacement, fly ash, nano silica and crumb rubber as additives with the watercementitious material ratio on the fresh of cement paste are outlined as below:

- The higher the compressive strength, the lower the void ratio and permeability.

- A higher amount of cement ratio in the mix design results in a lower void ratio and permeability but also increases the compressive strength of the concrete.

- High crumb rubber ratio in the mix design results in lower void ratio and permeability as it fills the void of the concrete mixture because of its small size.

\section{CONSENT FOR PUBLICATION}

Not applicable.

\section{AVAILABILITY OF DATA AND MATERIALS}

The authors confirm that the data supporting the findings of this study are available within the article.

\section{FUNDING}

The study is supported by the Universiti Teknologi PETRONAS for the testing facilities as well as financial support from iRMC Bold2025, Universiti Tenaga Nasional, Malaysia. (Grant Code: RJO 1043 6494.)

\section{CONFLICT OF INTEREST}

The authors declare no conflict of interest, financial or otherwise.

\section{ACKNOWLEDGEMENTS}

We are gratefully acknowledging the Universiti Teknologi PETRONAS for the continuous support.

\section{REFERENCES}

[1] P.D. Tennis, M.L. Leming, and D.J. Akers, Pervious concrete pavements, Portland Cement Association: Illinois, 2014.

[2] X. Cui, J. Zhang, D. Huang, Z. Liu, H. Fei, C. Sheqiang, L. Zhang, and Z. Wang, "Experimental study on the relationship between permeability and strength of pervious concrete", J. Mater. Civ. Eng., vol. 29 , no. 11, 2017.04017217

[http://dx.doi.org/10.1061/(ASCE)MT.1943-5533.0002058]

[3] D.H. Nguyen, N. Sebaibi, M. Boutouil, L. Leleyter, and F. Baraud, "A modified method for the design of pervious concrete mix", Constr. Build. Mater., vol. 73, pp. 271-282, 2014.

[http://dx.doi.org/10.1016/j.conbuildmat.2014.09.088]

[4] W. Goede, "Investigation into the structural performance of pervious concrete", J. Transp. Eng., vol. 138, no. 1, pp. 98-104, 2012. [http://dx.doi.org/10.1061/(ASCE)TE.1943-5436.0000305]

[5] J. Harvey, and D. R. Smith, "Permeable pavement road mao workshop and proposed road map for permeable pavement", A Workshop Report from the National Center for Sustainable Transportation, 2018.

[6] W. Shen, L. Shan, T. Zhang, H. Ma, Z. Cai, and H. Shi, "Investigation on polymer-rubber aggregate modified porous concrete", Constr. Build. Mater., vol. 38, pp. 667-674, 2013.

[http://dx.doi.org/10.1016/j.conbuildmat.2012.09.006]

[7] M. Gesoglu, E. Güneyisi, G. Khoshnaw, and S. Ipek, "Investigating properties of pervious concretes containing waste tire rubbers", Constr. Build. Mater., vol. 63, pp. 206-213, 2014.

[http://dx.doi.org/10.1016/j.conbuildmat.2014.04.046]

[8] A. Bonicelli, L.G. Fuentes, and I.K.D. Bermejo, "Laboratory investigation on the effects of natural fine aggregates and recycled waste tire rubber in pervious concrete to develop more sustainable pavement materials", In: IOP Conf. Series: Materials Science and Engineering, 2017.

[http://dx.doi.org/10.1088/1757-899X/245/3/032081]

[9] K.H. Boon, Y. David, and N. Jamaluddin, "Properties of pervious concrete containing scrap tyre tubes", In: MATEC Web of Conferences, 2017.

[http://dx.doi.org/10.1051/matecconf/201710301015]

[10] V.S. Prathibha, and G. Takhelmayum, Evaluation of structural performance of pervious concrete containing waste tire rubbers., 
International Journal of Advances in Scientific Research and Engineering, 2017, pp. 412-418.

[11] Y. Liu, T. Li, and H. Peng, "A new structure of permeable pavement for mitigating urban heat island", Sci. Total Environ., vol. 634, pp. 1119-1125, 2018.

[http://dx.doi.org/10.1016/j.scitotenv.2018.04.041] [PMID: 29660868]

[12] B.S. Mohammed, M.S. Liew, W.S. Alaloul, V.C. Khed, C.Y. Hoong, and M. Adamu, "Properties of nano-silica modified pervious concrete", In: Case Studies in Construction Materials, 2018, pp. 409-422.

[13] J.T. Kevern, K. Wang, and V.R. Schaefer, "Pervious concrete in severe exposures", Concr. Int., vol. 30, pp. 43-49, 2008.

[14] ASTM C230 / C230M-14, "Standard specification for flow table for use in tests of hydraulic cement", In: ASTM International, West Conshohocken, PA, 2004

[15] ASTM C1688 / C1688M-14a, "Standard test method for density and void content of freshly mixed pervious concrete", ASTM International, West Conshohocken, PA, 2014.

[16] ASTM C191-18a, "Standard test methods for time of setting of hydraulic cement by vicat needle", ASTM International, West
Conshohocken, PA, 2018.

17] J. Yang, and G. Jiang, "Experimental study on properties of pervious concrete pavement", Cement Concr. Res., vol. 33, pp. 381-386, 2003. [http://dx.doi.org/10.1016/S0008-8846(02)00966-3]

18] P. Chindaprasirt, S. Hatanaka, T. Chareerat, N. Mishima, and Y. Yuasa, "Cement paste characteristics and porous concrete properties", Constr. Build. Mater., vol. 22, no. 5, pp. 894-901, 2006. [http://dx.doi.org/10.1016/j.conbuildmat.2006.12.007]

[19] M.J. Webster, W. Xiaozheng, and Z. Aisha, "Rheology and setting time of cement paste", American Journal of Civil Engineering and Architecture, vol. 3, no. 6, pp. 208-211, 2015.

[20] S. Meherier, N. Banthia, and M.S. Alam, "Mechanical behavior of cement mortar with varying replacement level of crumb rubber", In: Fifth International Conference on Construction Materials: Performance, Innovations and Structural Implications, 2015. Whistler

[21] T.E. Swee, "Development of high permeable concrete block pavement to promote infiltration", Universiti Tenaga Nasional, , 2008

[22] K. C'osic, L. Korat, and V. Ducman, "Influence of aggregate type and size on properties of pervious concrete", Constr. Build. Mater, vol. 78, pp. 69-76, 2015.

[http://dx.doi.org/10.1016/j.conbuildmat.2014.12.073]

\section{(C) $2019 \mathrm{Ng}$ et al.}

This is an open access article distributed under the terms of the Creative Commons Attribution 4.0 International Public License (CC-BY 4.0), a copy of which is available at: https://creativecommons.org/licenses/by/4.0/legalcode. This license permits unrestricted use, distribution, and reproduction in any medium, provided the original author and source are credited. 